\title{
IMPROVING STUDENTS' ATTITUDE, CONCEPTUAL UNDERSTANDING AND PROCEDURAL SKILLS IN DIFFERENTIAL CALCULUS THROUGH MICROSOFT MATHEMATICS
}

\author{
Marie Jean N. Mendezabal (D), Darin Jan C. Tindowen (D) \\ University of Saint Louis (Philippines) \\ marie_jean_mendezabal@yahoo.com.ph,djtindowenn2015@gmail.com
}

Received December 2017

Accepted April 2018

\section{Abstract}

This study examined the effects of using Microsoft Mathematics on students' attitude, conceptual understanding, and procedural skills in Differential Calculus. A quasi-experimental research design was used in which two different learning environments were compared. The participants of the study were two classes of Electrical Engineering students enrolled in Differential Calculus course, assigned randomly as control and experimental groups with 30 students in each group. The control group was taught using the traditional approach of teaching Differential Calculus while the experimental group was taught the same lessons using the Microsoft Mathematics embedded activity sheets. The experimental group learned through exploration and discovery of various concepts. The findings indicated that the participants had little understanding of the concepts and processes of Calculus prior to the conduct of the study. A significant improvement in their performances was noted after the experimentation. This suggests that the use of Microsoft Mathematics in teaching and learning Differential Calculus improves students' conceptual understanding and procedural skills. It is also found that the use of Microsoft Mathematics in teaching and learning calculus is equally effective as the traditional approach. In terms of attitude, the experimental group demonstrated a "favorable" to "very highly favorable" attitude along the five (5) domains of the MTAS. A significant difference exists between the pretest and posttest attitude of the participants on the domain "learning Mathematics with technology".

Keywords - Differential calculus, Conceptual understanding, Procedural skills, Attitude, Technology, Microsoft mathematics

\section{Introduction}

The $21^{\text {st }}$ century learning landscape has dramatically changed due to the advent of technologies. Teaching and learning processes have become more interactive, engaging and fun through technology-based instruction. With the integration of technology in the classroom, educators continue to create learning materials that are innovative, task-oriented as well as learner-centered (Saavedra \& Opfer, 2012; Kim, Choi, Han \& So, 2012; Tindowen, Bassig \& Cagurangan, 2017).

In the field of Mathematics education, technology has already been integrated; however, its implementation seems slow (Agyei \& Voogt, 2011; De Witte \& Rogge, 2014; Safdar, Yousuf, Parveen \& Behlol, 2011). Moreover, studies which focused on the integration of technology in Mathematics teaching and learning present divergent results. While some researches concede that the use of technology in Mathematics teaching and learning has not led to any discernible improvements (Goodison, 2002; 
Hourigan \& O'Donoghue, 2007; Biagi \& Loi, 2013), others have shown that the use of technology effectively enhance students' understanding and enjoyment of Mathematics (Miller \& Glover, 2007; Tay, Lim, Lim \& Koh, 2012). It is identified as a tool and important component to support visualization and interactive media that assist representation, reasoning, calculation construct, exploring, and solving problem (Curri, 2012).

Calculus is a branch of Mathematics which has a wide application in almost all disciplines such as engineering, science, business, computer science, and information system. It is an area of Mathematics perceived as the main source of failure in the undergraduate level because of its nature which involves abstract and complex ideas and the way it is being taught to the students (Sahin, Cavlazoglu \& Zeytuncu, 2015). With these, initiatives around the world have introduced a range of innovative and interactive learning technologies such as graphic software (Robutti, 2010; Lavizca, 2010) and computer algebra system (Özgün-Koca, 2010; Mignotte, 2012; Durán, Pérez \& Varona, 2014) to explore Calculus concepts. The use of these technologies offer new ways to learn and teach Calculus that help deepen students' understanding of abstract and complex ideas (Arango, Gaviria \& Valencia, 2015; Šumonja, Veličković \& Šubarević, 2015; Zakaria \& Salleh, 2015) which include conceptual understanding (Bartell, Webel, Bowen \& Dyson, 2013; Richland, Stigler \& Holyoak, 2012) and procedural skills (Rittle-Johnson \& Schneider, 2014; Cragg \& Gilmore, 2014) and also increases positive attitude of students towards the subject (Sang, Valcke, Van Braak \& Tondeur, 2010; Yuan \& Chun-Yi, 2012). Further, it helps students to better visualize the concepts through graphical representation (Moses, Wong, Bakar \& Mahmud, 2013). Previous researches have concluded that interactive technology especially visualization tools like graphing calculators and other Mathematics software, are an effective media to engage students in the learning and create meaningful learning (Liang \& Sedig, 2010; Arsan, Kutluca \& Özpınar, 2011).

In the Philippines, a developing country in South East Asia, students' performance in Calculus has never been encouraging. At present, Calculus is considered as one of the most challenging and difficult major courses of college students in the Philippines (Angeles, Fajardo \& Tanguilig III, 2015; Salazar, 2016). In fact, the result of the Trends in International Mathematics and Science Study in 2008 revealed that the Philippines performed least among ten countries in mathematics in which students performed weak in the Calculus subject (Ogena, Lana \& Sasota, 2010). Moreover, it is also viewed as boring and strictly procedural subject (Matthews, Hoessler, Jonker \& Stockley, 2013). In many Calculus classes, the traditional approach which puts emphasis on computational procedures rather than on understanding the underlying concepts is still the most commonly used method by teachers (Lasut, 2015). As a result, many students fail to manifest excellent performance in the subject, more so students do not know how to apply the concepts in real life situation (Fluck \& Dowden, 2013; Nobre, Meireles, Junior, De Resende, Da Costa \& Da Rocha, 2016).

Teaching Calculus using the traditional approach does not help students understand the basic concepts (Axtell, 2006). Thus, the teaching and learning of Calculus should be improved focusing on the conceptual understanding of the subject, as well as the development of problem solving skills. This is to prepare students for the challenges of the $21^{\text {st }}$ century society especially now that Calculus is a required subject in the STEM (Science, Technology, Engineering, and Mathematics) strand of the Senior High School (SHS) curriculum. This challenges every Mathematics teacher to employ an approach that provides opportunities for the students to investigate and explore various mathematical concepts using different representations.

This study was conducted to investigate the effectiveness of using Microsoft Mathematics in the teaching and learning of Differential Calculus. It specifically tried to look into the performances on the conceptual understanding and procedural skills of students towards Calculus subject utilizing the said mathematics software. Moreover, it will also look into the overall attitude of the students before and after the use of Microsoft Mathematics in teaching and learning Calculus subject. 


\subsection{The Use of Microsoft Mathematics in Mathematics Instruction}

Microsoft Mathematics is a freeware made by Microsoft Corporation to help students solve and understand mathematical concepts with visual effect and easy to understand steps. The primary tool in Microsoft Mathematics is a full-featured scientific calculator with extensive graphing and equation-solving capabilities. It can be used just like a handheld calculator by clicking buttons or the computer keyboard to type the mathematical expressions that you want the calculator to evaluate. It's capable of handling subjects including Pre-algebra, Algebra, Trigonometry, Calculus, Physics and Chemistry. There are three benefits using Microsoft Mathematics in learning Mathematics, these are freeware with structured menu and some of the menu provides solution and visualization (Microsoft Corporation, 2010).

\section{Methodology}

The study made use of the quasi-experimental with pretest-posttest, experimental-control group design in which two different learning environments were compared. It also employed the descriptive research design where an attitudinal questionnaire was utilized to determine the effect of using Microsoft Mathematics on students' attitude. Two classes of Electrical Engineering students of a private university in the Philippines enrolled in Differential Calculus were involved in the study. The two groups were selected as these were scheduled on the same time slot but different days. One class was assigned randomly as experimental group and the other as control group. Participants in both groups were identified and matched based on their grade point average (GPA) in their previous Mathematics subjects which are pre-requisites of Differential Calculus. Students with an average grade of 75-86 were included in the study. Results of the pretest that were administered before the conduct of the study were likewise considered in the selection. To ensure that the participants in both groups were of the same level of mental ability, the significant difference in the means of the pretest was tested using t-test of independent samples.

\subsection{Research Instruments}

\subsubsection{The Mathematics and Technology Attitude Scale (MTAS)}

The Mathematics and Technology Attitude Scale (MTAS) developed by Pierce, Stacey \& Barkatsas (2007) was adopted in this study; however, some modifications were made specifically on the descriptive value assigned and the technology used to suit to the present study. The scale was used to monitor five affective variables relevant to learning mathematics with technology. The subscales measure mathematics confidence, confidence with technology, attitude to learning mathematics with technology and two aspects of engagement in learning mathematics.

\subsubsection{Pretest and Posttest}

The pretest/posttest is a teacher-made test composed of 25-item multiple choice to assess students conceptual understanding and 15-item open-response problem solving (scored 5 points per item using a rubric with a total of 75 points) for procedural skills. The test covered the topics in Differential Calculus namely: limits, continuity, derivatives, increasing and decreasing functions, and maximum and minimum values of a function. The test was validated by Mathematics experts and revised based on their suggestions.

\subsubsection{Technology-based Activity Sheets}

The technology-based activity sheets were developed for use by the experimental group. These activity sheets were designed following the principle of Rule of Three: graphical, numerical, and analytical approach. Each activity or lesson included the following parts:

1. Topic which is the lesson to be learned which includes limits, continuity, derivative, increasing and decreasing functions, and maximum and minimum values of a function;

2. Learning Outcomes which describes what the learner should manifest after conducting the activity; 
3. Activity which is performed with specific purpose;

4. Further Exploration to enrich students understanding of Calculus concepts;

5. Key Concept which is a definition, formula, etc.

6. Self-Test which consists of items for more drills and practice; and

7. Evaluation to assess students' learning.

The activity sheets were critiqued by Calculus teachers and other experts in the field. These activities were revised based on the comments and suggestions provided by the evaluators.

\subsection{Data Analysis}

The data gathered were analyzed using descriptive statistics such as frequency count and mean to describe the pretest and posttest performances of the participants in both groups. The t-test for Independent Samples was used to compare the pretest and posttest performances of the two groups. Similarly, the t-test for Paired Samples was employed to compare the performance and attitude of the experimental group before and after the experimentation.

To measure the attitude of the experimental group toward learning mathematics with technology, a Likert-type scoring format was used for each of the subscales: Mathematics Confidence [MC], Confidence with Technology [TC], Attitude to learning Mathematics with Technology [MT], Affective Engagement [AE] (scored from 5-strongly agree to 1-strongly disagree). A different but similar response set was used for the Behavioral Engagement $[\mathrm{BE}]$ subscale. A five-point system was again used - Always, Often, Regularly, Rarely, Never (scored again from 5 to 1).

\section{Results and Discussion}

\subsection{Pretest and Post-test Performance of Participants in the Experimental and Control Groups} on Conceptual Understanding and Procedural Skills Tests

Table 1 presents the pretest and posttest performances of the participants from the experimental and control group. As reflected in the table, majority of the students in both groups have pretest scores ranging from 6-10. This result indicates that they performed fairly in the pretest. The table also reveals that the experimental and control groups have the same pretest mean score of 8.27 which means both groups have fair performance before the conduct of the study. The value further indicates that the students do not have much knowledge of the important concepts in Differential Calculus.

\begin{tabular}{|c|c|c|c|c|c|c|c|c|}
\hline \multirow{3}{*}{ Scores } & \multicolumn{4}{|c|}{$\begin{array}{l}\text { Experimental Group } \\
\qquad(\mathrm{n}=30)\end{array}$} & \multicolumn{4}{|c|}{$\begin{array}{l}\text { Control Group } \\
\quad(\mathrm{n}=30)\end{array}$} \\
\hline & \multicolumn{2}{|c|}{ Pretest } & \multicolumn{2}{|c|}{ Posttest } & \multicolumn{2}{|c|}{ Pretest } & \multicolumn{2}{|c|}{ Posttest } \\
\hline & F & $\%$ & F & $\%$ & $F$ & $\%$ & $F$ & $\%$ \\
\hline \multicolumn{9}{|l|}{$21-25$} \\
\hline $16-20$ & & & & & & & 2 & 6.70 \\
\hline $11-15$ & 4 & 13.30 & 14 & 46.70 & 4 & 13.30 & 15 & 50.00 \\
\hline $6-10$ & 24 & 80.00 & 16 & 53.30 & 23 & 76.70 & 11 & 36.60 \\
\hline $0-5$ & 2 & 6.70 & & & 3 & 10.00 & 2 & 6.70 \\
\hline Mean & \multicolumn{2}{|c|}{$8.27^{\mathrm{d}}$} & \multicolumn{2}{|c|}{$10.60^{c}$} & \multicolumn{2}{|c|}{$8.27^{\mathrm{d}}$} & \multicolumn{2}{|c|}{$10.50^{\mathrm{d}}$} \\
\hline
\end{tabular}

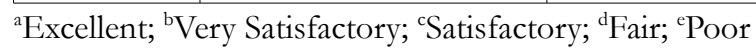

Table 1. Pretest and Posttest Performances of the Participants on Conceptual Understanding 
The result of this study is confirmed by the previous study in which it was found out that students enrolled in Engineering Technology courses were lacking a strong Calculus foundation as evidenced by their low achievement in the said subject (Zakaria \& Salleh, 2015). Accordingly, one of the reasons behind the low performance of students in Calculus is the deficiency in conceptual understanding (Liang \& Martin, 2008).

With regard to the posttest performance of the subjects, the table shows an improvement in the scores in both groups. Students in the experimental group have performance ranging from fair to satisfactory. The same performance is exhibited by majority of the students in the control group. The data likewise reveal that the mean score of the experimental and control groups are nearly equal. The experimental group obtained a mean score of 10.6 while the control group is 10.5. As reflected by the post-test mean scores, the conceptual understanding of the subjects in the experimental group is satisfactory while fair for the control group. The mean scores suggest that students have little understanding of the basic concepts in Calculus. Many students cannot achieve a deep understanding of the concepts and find that Calculus is very hard and abstract (Tiwari, 2007). The result of this study shared similar findings of previous studies conducted which have shown that students have difficulties in understanding the concepts of Integral Calculus (Liang \& Martin, 2008; Salleh \& Zakaria, 2011).

Table 2 shows the performance of the participants in the procedural skill test. As gleaned from the table, all students from the experimental and control groups performed poorly in the pretest with scores ranging from 0-15. Moreover, the table reveals a very low pretest mean scores for both groups. Further analysis of students' work shows that some students did not attempt to solve the given problems. Others tried but they failed to continue because of lack of knowledge or understanding of the Calculus ideas to solve problems. This result indicates that the students have little intuition about the concepts and processes of Calculus which confirms the previous result. It is possible that students simply guessed their answers in the conceptually-oriented test since the given test is a multiple choice type. Procedural and conceptual knowledge are complementary (Bossé \& Bahr, 2008) since procedural knowledge is part of conceptual knowledge (Tall, 2008).

The data also reveal that more than three-quarters $(76.7 \%)$ of the experimental group and over half $(56.7 \%)$ of the control group have at least satisfactory performance in the posttest. Moreover, the experimental group obtained a mean score of 36.83 while the control group had a mean score of 33.77 , both of which indicate a satisfactory performance. This result implies that both groups improved in their performance after the experimentation. However, the experimental group has achieved higher posttest mean score than the control group. This result suggests that the use of the traditional approach and the technology-based approach in Mathematics teaching and learning can improve Mathematics performance.

\begin{tabular}{|c|c|c|c|c|c|c|c|c|}
\hline \multirow{3}{*}{ Scores } & \multicolumn{4}{|c|}{$\begin{array}{l}\text { Experimental Group } \\
\qquad(\mathrm{n}=30)\end{array}$} & \multicolumn{4}{|c|}{$\begin{array}{l}\text { Control Group } \\
\quad(n=30)\end{array}$} \\
\hline & \multicolumn{2}{|c|}{ Pretest } & \multicolumn{2}{|c|}{ Posttest } & \multicolumn{2}{|c|}{ Pretest } & \multicolumn{2}{|c|}{ Posttest } \\
\hline & $F$ & $\%$ & F & $\%$ & F & $\%$ & F & $\%$ \\
\hline $61-75$ & & & & & & & 2 & 6.70 \\
\hline $46-60$ & & & 3 & 10.00 & & & 2 & 6.70 \\
\hline $31-45$ & & & 20 & 66.70 & & & 13 & 43.30 \\
\hline $16-30$ & & & 7 & 23.30 & & & 13 & 43.30 \\
\hline $0-15$ & 30 & 100 & & & 30 & 100.00 & & \\
\hline Mean & \multicolumn{2}{|c|}{$4.77^{\mathrm{e}}$} & \multicolumn{2}{|c|}{$36.83^{\mathrm{c}}$} & \multicolumn{2}{|c|}{$3.93^{\mathrm{e}}$} & \multicolumn{2}{|c|}{$33.77^{\mathrm{c}}$} \\
\hline
\end{tabular}

${ }^{a}$ Excellent; ${ }^{\mathrm{b}}$ Very Satisfactory; ${ }^{\mathrm{c}}$ Satisfactory; ${ }^{\mathrm{d}} \mathrm{Fair} ;{ }^{\mathrm{e}}$ Poor

Table 2. Pretest and posttest performances of the participants on procedural skills 


\subsection{Test of Significant Difference in the Pretest and Posttest Performances of the Experimental and Control Groups}

As shown in the table, there is no statistically significant difference between the pretest mean scores of the experimental and control groups in both conceptually-oriented and procedural skill tests. This implies that the two groups have comparable mathematical ability prior to the conduct of the study.

The posttest mean score of the two groups reveals no statistically significant difference. The t-value of 0.146 and $\mathrm{p}$-value of 0.884 for the conceptually-oriented test and t-value of 1.178 and $\mathrm{p}$-value of 0.243 for the procedural skill test indicates that the posttest performances of the experimental and control groups do not differ significantly. The result suggests that the integration of technology in the teaching and learning of Calculus is equally effective as the traditional approach.

The research findings are supported by many studies who tried to compare the procedural skills of students in experimental groups, taught by using ICT with those from control groups taught traditionally (Code, Piccolo, Kohler \& MacLean, 2014; Arslan, 2010; Czocher, Tague \& Baker, 2013). Result of these studies found that there is no significant difference between the two groups. Also students' achievement taught by using Microsoft Mathematics was higher than those taught by traditional teaching method (Purwanti \& Pustari, 2013). However, the finding of the study likewise revealed that the difference between groups in terms of the improvement score was not significant. Furthermore, Calculus knowledge in students exposed to teacher-centered and student-centered teaching approach found no statistical significance in success between the two groups of students (Schumacher \& Kennedy, 2008).

\begin{tabular}{|c|c|c|c|c|}
\hline \multicolumn{1}{|c|}{ Domain } & Group & Mean & t-value & p-value \\
\hline \multirow{2}{*}{ Conceptual Understanding } & Experimental & 8.27 & \multirow{2}{*}{0.000} & 1.000 \\
\cline { 2 - 5 } & Control & 8.27 & & \multirow{2}{*}{0.187} \\
\hline \multirow{2}{*}{ Procedural Skills } & Experimental & 4.77 & 1.335 & \\
\cline { 2 - 5 } & Control & 3.93 & & \\
\hline
\end{tabular}

*Significant at 0.01 level

Table 3. Significant Difference in the Pretest Performances of the Experimental and Control Groups

\begin{tabular}{|c|c|c|c|c|}
\hline \multicolumn{1}{|c|}{ Domain } & Group & Mean & t-value & p-value \\
\hline \multirow{2}{*}{ Conceptual Understanding } & Experimental & 10.60 & \multirow{2}{*}{0.146} & \multirow{2}{*}{0.884} \\
\cline { 2 - 4 } & Control & 10.50 & & \multirow{2}{*}{0.243} \\
\hline \multirow{2}{*}{ Procedural Skills } & Experimental & 36.83 & \multirow{2}{*}{1.178} & \\
\cline { 2 - 5 } & Control & 33.77 & & \\
\hline
\end{tabular}

*Significant at 0.01 level

Table 4. Significant Difference in the Posttest Performances of the Experimental and Control Groups

\subsection{Test of Significant Difference in the Pretest and Posttest Performances of the Experimental Group}

\begin{tabular}{|c|c|c|c|c|c|}
\hline Domain & Test & Mean & Mean Difference & t-value & p-value \\
\hline \multirow{2}{*}{ Conceptual Understanding } & Pretest & 8.27 & \multirow{2}{*}{2.333} & \multirow{2}{*}{4.436} & \multirow{2}{*}{$.000^{*}$} \\
\hline & Posttest & 10.60 & & & \\
\hline \multirow{2}{*}{ Procedural Skills } & Pretest & 4.77 & \multirow{2}{*}{32.067} & \multirow{2}{*}{22.067} & \multirow{2}{*}{$.000 *$} \\
\hline & Posttest & 36.83 & & & \\
\hline
\end{tabular}

*Significant at 0.01 level

Table 5. Significant Difference in the Pretest and Posttest Performance of the Experimental Group 
As disclosed in the table, the pretest mean score for the conceptually-oriented test is 8.27 while the post-test mean score is 10.6. The difference of 2.33 in the pretest and posttest scores reflects a significant increase in the performance of students in the experimental group. This indicates that the mean score after the experimentation is significantly higher than the mean score before the experimentation. The paired $\mathrm{t}$ statistic that resulted is 4.436 with statistical significance $\mathrm{p}=0.000<.01$. This result implies a significant difference in the scores.

Similar result is demonstrated for the procedural skill test. The mean difference of 32.067 provides evidence that students' performance in the post-test is higher than in the pre-test. The probability value of .000 also reveals a significant difference in the pretest and posttest scores of the participants.

Overall, students achieved higher scores on the posttest than on the pretest after integrating Microsoft Mathematics in Calculus teaching and learning. The result clearly shows that the use of Microsoft Mathematics improved both students' conceptual understanding and procedural skills in Differential Calculus. The results of this study are consistent with the findings of similar studies on the utilization of mathematics software in teaching such as on Applications of Geogebra into Teaching Some Topics of Mathematics at the College Level (Diković, 2009). The study confirmed that the use of the applets created with the help of GeoGebra and used in Differential Calculus teaching had a positive effect on the understanding and knowledge of the students. The paired samples t-test revealed a significant difference in scores before and after the GeoGebra workshops. Moreover, studies were conducted examining the effect of integrating technology in students' conceptual and procedural understanding of Integral Calculus and concluded that students benefitted from the integration of mathematics software in learning Integral Calculus (Salleh \& Zakaria, 2013). Both types of understanding were found to be successfully enhanced using the mathematical software.

\subsection{Attitude of the Experimental Group towards Learning Mathematics with Technology Before and After the Experimentation}

\begin{tabular}{|l|c|l|c|l|}
\hline \multirow{2}{*}{\multicolumn{1}{|c|}{ Dimensions }} & \multicolumn{2}{c|}{ Pretest } & \multicolumn{2}{c|}{ Posttest } \\
\cline { 2 - 5 } & Mean & Qualitative Description & Mean & \multicolumn{1}{c|}{ Qualitative Description } \\
\hline Mathematics Confidence & 3.38 & Favorable & 3.48 & Highly Favorable \\
\hline Confidence with Technology & 3.40 & $\begin{array}{l}\text { Highly } \\
\text { Favorable }\end{array}$ & 3.40 & $\begin{array}{l}\text { Highly } \\
\text { Favorable }\end{array}$ \\
\hline Learning Mathematics with Technology & 2.63 & Favorable & 3.56 & Highly Favorable \\
\hline Affective Engagement & 4.37 & Very Highly Favorable & 4.29 & Very Highly Favorable \\
\hline Behavioral Engagement & 3.77 & Highly Favorable & 3.82 & Highly Favorable \\
\hline Overall Mean Attitude & 3.51 & Highly Favorable & 3.71 & Highly Favorable \\
\hline
\end{tabular}

Table 6. Students' Overall Attitude Toward Learning Mathematics with Technology

Table 6 presents the students' overall attitude along five dimensions of learning mathematics with technology. The findings show improvement in the attitude of the students towards learning mathematics in terms of their mathematics confidence. An increase of mean score from "favorable" to "highly favorable" signifies that the use of technology in learning Mathematics improved students' mathematics confidence. In addition, the students' strongly agreed that they have a mathematical mind and can handle difficulties in Mathematics.

Moreover, as observed in the table, students have highly favorable attitude related to confidence with technology which is revealed in the overall mean score. The students strongly agreed that they have the ability to use technology. Students stated that they are good users of computers and other things like VCRs, DVDs, MP3s and mobile phones. This result is expected as today's students are "digital natives". Students likewise asserted that they can master any computer program needed for school; however, they only agree that they can fix a lot of computer problems. The finding of this study concurs with the 
findings of Zakaria and Salleh (2015) that the students involved in the study on "Using Technology in Learning Integral Calculus" had very high positive value towards using computers in their daily activities. Also, in the study of Oktaviyanthi and Supriani (2014), it was found out that students had very good attitude in terms of computer confidence, but their proficiency level related to educational technology is average.

Meanwhile, learning mathematics with technology has greatly changed the attitude of the students from "favorable" to "highly favorable". This means that the attitude of the students regarding the use of technology in learning Mathematics improved after the implementation of the technology-based activities. The students became more interested in learning Differential Calculus through the use of Microsoft Mathematics and this has resulted in more engagement in learning. The integration of Microsoft Mathematics in the teaching and learning process enabled the students to explore and link the different relations and concepts in Calculus through the different representations (i.e. graphical, numerical, and analytical) which were difficult to explain without technology. Further, the students disclosed that the use of technology in learning mathematics is worth the extra effort. The finding of this study supports the research findings of many researchers that applying technology in mathematics learning increases students' motivation (Nguyen \& Kulm 2005; Ekawati, 2008) and engagement in classroom learning activities (Prasek, Schwartz \& Vorst, 2012; Al-Absi \& Abed, 2014; Al-Ammary, 2012).

Furthermore, the data in the table also show that generally students have very highly favorable attitude in terms of the affective engagement. Based on students' responses, they stated that learning mathematics is enjoyable. This has been observed in the students while working on the technology-based activities wherein they are actively involved in the mathematics learning process. The students strongly believe that in Mathematics they get rewards for their efforts. Furthermore, the students avowed that they are interested in learning new things in mathematics and they find it emotionally satisfying when they solve mathematics problems as revealed in their responses which is "very highly favorable"; although there is a slight decrease in the posttest mean attitude of the students which may be attributed to the nature and complexity of the subject.

In addition, the table reveals a highly favorable attitude of the students as to behavioral engagement as shown in the pretest and posttest mean attitude. The students stated that they concentrate hard in mathematics. The students further affirmed that if they cannot do a problem, they keep on trying different ideas or approaches. With these, the implementation of technology in learning makes students very attentive and engaged in learning (Prasek, Schwartz \& Vorst, 2012). Moreover, the use of studentcentered and active learning approach develops the potential of individuals to be more creative and critical in their thinking (Mokhtar, Tarmizi, Ayib \& Tarmizi 2010).

In summary, the data reveal that generally students have "highly favorable" attitude toward learning mathematics with technology even before the experimentation, although the posttest mean attitude of the subjects is higher than the pretest mean attitude. The table further reveals an improvement in the attitude of the subjects in terms of their mathematics confidence and learning mathematics with technology. The data suggest that the participants have more favorable attitude in terms of these dimensions after their exposure to the technology-based approach of teaching and learning Mathematics.

\subsection{Test of Significant Difference in the Pretest and Posttest Attitude of the Experimental Group}

As shown in the table, there is a statistically significant difference in the pretest and posttest mean attitude of the students with regard to learning Mathematics with technology. The mean difference of 0.933 denotes a significant increase in the posttest mean attitude of the students. This is further validated by the $\mathrm{t}$-value of 3.336 and probability value of 0.002 , which is less than the 0.05 level of significance. This result implies that the use of Microsoft Mathematics in Differential Calculus positively influenced the attitude of students toward learning mathematics with technology. 


\begin{tabular}{|c|c|c|c|c|c|}
\hline Dimension & Test & Mean & Mean Difference & t-value & p-value \\
\hline \multirow{2}{*}{ Mathematics Confidence } & Pretest & 3.3750 & \multirow{2}{*}{.10556} & \multirow{2}{*}{.971} & \multirow{2}{*}{.339} \\
\hline & Posttest & 3.4806 & & & \\
\hline \multirow{2}{*}{ Confidence with Technology } & Pretest & 3.4000 & \multirow{2}{*}{.00000} & \multirow{2}{*}{.000} & \multirow{2}{*}{1.000} \\
\hline & Posttest & 3.4000 & & & \\
\hline \multirow{2}{*}{$\begin{array}{l}\text { Learning Mathematics with } \\
\text { Technology }\end{array}$} & Pretest & 2.6250 & \multirow{2}{*}{.93333} & \multirow{2}{*}{3.336} & \multirow{2}{*}{$.002^{*}$} \\
\hline & Posttest & 3.5583 & & & \\
\hline \multirow{2}{*}{ Affective Engagement } & Pretest & 4.3667 & \multirow{2}{*}{.07500} & \multirow{2}{*}{619} & \multirow{2}{*}{.541} \\
\hline & Posttest & 4.2917 & & & \\
\hline \multirow{2}{*}{ Behavioral Engagement } & Pretest & 3.7667 & \multirow{2}{*}{.05000} & \multirow{2}{*}{.588} & \multirow{2}{*}{.561} \\
\hline & Posttest & 3.8167 & & & \\
\hline
\end{tabular}

*Significant at 0.05 level

Table 7. Significant Difference in Students' Attitude Before and After the Use of Microsoft Mathematics

The data likewise reveal that although there is no significant difference in the attitude of the subjects in terms of mathematics confidence, confidence with technology, affective engagement, and behavioral engagement, a favorable attitude along these domains has been demonstrated by the students. The increase in the posttest mean attitude of the students in terms of mathematics confidence mirrors an increased confidence in doing mathematics.

\section{Conclusion and Implications for Further Research}

The use of Microsoft Mathematics in teaching and learning Differential Calculus improves students' conceptual understanding, procedural skill, and attitude toward learning the subject; it is equally effective as the traditional approach. With the Microsoft Mathematics embedded activities, students are afforded the opportunities to learn Calculus concepts and processes by exploration and discovery allowing them to be more engaged in learning.

In view, mathematics teachers are encouraged to integrate technology in Mathematics instruction to diversify their teaching approach and make it more interactive. Calculus teachers can use the Microsoft Mathematics embedded activity sheets to supplement lectures and to enable the students gain further understanding of Calculus concepts and develop their problem-solving ability.

Moreover, teachers should continue to engage students in meaningful learning by providing technology-based learning environment that allows students to experience the process of mathematical investigation and foster positive attitude toward the subject. Mathematics educators must continue to examine current practices for teaching Mathematics with technology to determine its effectiveness and to explore new ways to harness the potential that it brings as an instructional and learning tool.

A possible extension of this study is to look into other technology-driven instructional strategies and activities such as mathematics software that will also enhance students' attitude, conceptual skills, ad procedural skills in Calculus and other mathematics courses.

Similar study may also be conducted to other programs such as Technical and other engineering programs since the participants of this present study were the Electrical Engineering students.

\section{Declaration of Conflicting Interests}

The authors declared no potential conflicts of interest with respect to the research, authorship, and/or publication of this article.

\section{Funding}

The authors gratefully acknowledge the financial support provided by the University of Saint Louis and the Commission on Higher Education (CHED) for the research. 


\section{References}

Agyei, D.D., \& Voogt, J. (2011). ICT use in the teaching of mathematics: Implications for professional development of pre-service teachers in Ghana. Education and Information Technologies, 16(4), 423-439.

https://doi.org/10.1007/s10639-010-9141-9

Al-Absi, M.M., \& Abed, E.R. (2014). The confidence level of the technology use in learning mathematics from class teacher students' point of view and its relation to certain variables. International Journal of Humanities and Social Science, 4(1), 179-186.

AlAmmary, J. (2012). Educational technology: A way to enhance student achievement at the University of Bahrain. Procedia-Social and Behavioral Sciences, 55, 248-257. https://doi.org/10.1016/j.sbspro.2012.09.501

Angeles, M.R., Fajardo, A.C., \& Tanguilig III, B.T. (2015). E-Math Version 2.0, a Learning Management System as a Math Reviewer Tool for Engineering Students in the Philippines. International Journal of Engineering and Technical Research, 3(2), 18-21. Available at: http://www.academia.edu/11863180/EMath Version 2.0 a Learning Management System as a Math Reviewer Tool for Engineering Students in t he Philippines

Arango, J., Gaviria, D., \& Valencia, A. (2015). Differential calculus teaching through virtual learning objects in the field of management sciences. Procedia-Social and Behavioral Sciences, 176, 412-418. https://doi.org/10.1016/j.sbspro.2015.01.490

Arsan, S., Kutluca, T., \& Özpınar, İ. (2011). Investigating mathematics teacher candidates opinions about using information \& communication technologies. Cypriot Journal of Educational Sciences, 6(2), 75-82.

https://doi.org/goo.gl/B85q6w

Arslan, S. (2010). Traditional instruction of differential equations and conceptual learning. Teaching Mathematics and its Applications: An International Journal of the IMA, 29(2), 94-107.

https://doi.org/10.1093/teamat/hrq001

Axtell, M. (2006). A Two-Semester Precalculus/calculus I Sequence: A Case Study. Mathematics and Computer Education, 40(2), 130. Available at:: goo.gl/fzF9dY

Bartell, T.G., Webel, C., Bowen, B., \& Dyson, N. (2013). Prospective teacher learning: recognizing evidence of conceptual understanding. Journal of Mathematics Teacher Education, 16(1), 57-79.

https://doi.org/10.1007/s10857-012-9205-4

Biagi, F., \& Loi, M. (2013). Measuring ICT use and learning outcomes: Evidence from recent econometric studies. European Journal of Education, 48(1), 28-42. https://doi.org/10.1111/ejed.12016

Bossé, M.J., \& Bahr, D.L. (2008). The State of Balance between Procedural Knowledge and Conceptual Understanding in Mathematics Teacher Education. International Journal of Mathematics Teaching and Learning. Available at: http://www.cimt.org.uk/journal/bossebahr.pdf

Code, W., Piccolo, C., Kohler, D., \& MacLean, M. (2014). Teaching methods comparison in a large calculus class. ZDM, 46(4), 589-601. https://doi.org/10.1007/s11858-014-0582-2

Cragg, L., \& Gilmore, C. (2014). Skills underlying mathematics: The role of executive function in the development of mathematics proficiency. Trends in Neuroscience and Education, 3(2), 63-68.

https://doi.org/10.1016/j.tine.2013.12.001

Curri, E. (2012). Using computer technology in teaching and learning mathematics in an Albanian upper secondary school: the implementation of simReal in trigonometry lessons. Master's thesis. Universitetet i Agder, University of Agder. Available at: https://brage.bibsys.no/xmlui/handle/11250/138114

Czocher, J.A., Tague, J., \& Baker, G. (2013). Where does the calculus go? An investigation of how calculus ideas are used in later coursework. International Journal of Mathematical Education in Science and Technology, 44(5), 673-684. https://doi.org/10.1080/0020739X.2013.780215 
De Witte, K., \& Rogge, N. (2014). Does ICT matter for effectiveness and efficiency in mathematics education? Computers \& Education, 75, 173-184. https://doi.org/10.1016/j.compedu.2014.02.012

Diković, L. (2009). Applications GeoGebra into teaching some topics of mathematics at the college level. Computer Science and Information Systems, 6(2), 191-203. https://doi.org/10.2298/CSIS0902191D

Durán, A.J., Pérez, M., \& Varona, J.L. (2014). The Misfortunes of a Trio of Mathematicians Using Computer Algebra Systems. Can We Trust in Them? Notices of the AMS, 61(10), 1249-1252. Available at: http://www.ams.org/notices/201410/rnoti-p1249.pdf https://doi.org/10.1090/noti1173

Ekawati, E. (2008). Pembelajaran Matematika Berbatuan ICT dalam Meningkatkan Kemampuan Kognitif dan Kemampuan Afektif Siswa. PPPPTK Matematika. Jurnal Pendidikan Matematika ICT.

Fluck, A., \& Dowden, T. (2013). On the cusp of change: examining pre-service teachers' beliefs about ICT and envisioning the digital classroom of the future. Journal of Computer Assisted Learning, 29(1), 4352. https://doi.org/10.1111/j.1365-2729.2011.00464.x

Goodison, T. (2002). ICT and attainment at primary level. British Journal of Educational Technology, 33(2), 201-211. https://doi.org/10.1111/1467-8535.00253

Hourigan, M., \& O’Donoghue, J. (2007). Mathematical under-preparedness: the influence of the pretertiary mathematics experience on students' ability to make a successful transition to tertiary level mathematics courses in Ireland. International Journal of Mathematical Education in Science and Technology, 38(4), 461-476. https://doi.org/10.1080/00207390601129279

Kim, H., Choi, H., Han, J., \& So, H.J. (2012). Enhancing teachers' ICT capacity for the 21st century learning environment: Three cases of teacher education in Korea. Australasian Journal of Educational Technolog), 28(6). https://doi.org/10.14742/ajet.805

Lasut, M. (2015). Application of Information Computer-based Learning in Calculus Package Learning. International Journal of Scientific and Research Publications, 5(2). Available at: http://www.ijsrp.org/researchpaper-0215.php?rp=P383699

Lavicza, Z. (2010). Integrating technology into mathematics teaching at the university level. ZDM, 42(1), 105-119. https:// doi.org/10.1007/s11858-009-0225-1

Liang, H.N., \& Sedig, K. (2010). Can interactive visualization tools engage and support pre-university students in exploring non-trivial mathematical concepts? Computers \& Education, 54(4), 972-991. https://doi.org/10.1016/j.compedu.2009.10.001

Liang, J., \& Martin, L. (2008). An Excel-aided method for teaching calculus-based business mathematics. College Teaching Methods \& Styles Journal, 4(11), 11-23. https://doi.org/10.19030/ctms.v4i11.5576

Matthews, A.R., Hoessler, C., Jonker, L., \& Stockley, D. (2013). Academic motivation in calculus. Canadian Journal of Science, Mathematics and Technology Education, 13(1), 1-17. https://doi.org/10.1080/14926156.2013.758328

Microsoft Corporation (2010). Your students' interest will multiply with Microsoft $\mathbb{R}$ Mathematics. United States: Microsoft Corporation.

Mignotte, M. (2012). Mathematics for computer algebra. Springer Science \& Business Media.

Miller, D., \& Glover, D. (2007). Into the unknown: The professional development induction experience of secondary mathematics teachers using interactive whiteboard technology. Learning, Media and Technology, 32(3), 319-331. https://doi.org/10.1080/17439880701511156

Mokhtar, M.Z., Tarmizi, R.A., Ayub, A.F.M., \& Tarmizi, M.A.A. (2010). Enhancing calculus learning engineering students through problem-based learning. WSEAS transactions on Advances in Engineering Education, 7(8), 255-264. Available at: http://goo.gl/qEQFya 
Moses, P., Wong, S.L., Bakar, K.A., \& Mahmud, R. (2013). Perceived usefulness and perceived ease of use: antecedents of attitude towards laptop use among science and mathematics teachers in Malaysia. The Asia-Pacific Education Researcher, 22(3), 293-299. https://doi.org/10.1007/s40299-012-0054-9

Nguyen, D.M., \& Kulm, G. (2005). Using web-based practice to enhance mathematics learning and achievement. Journal of Interactive Online Learning, 3(3), 1-16. Available at: goo.gl/1TKR3o

Nobre, C.N., Meireles, M.R.G., Junior, N.V., De Resende, M.N., Da Costa, L.E., \& Da Rocha, R.C. (2016). The Use of Geogebra Software as a Calculus Teaching and Learning Tool. Informatics in Education, 15(2), 253. Available at: https://www.ceeol.com/search/article-detail?id=442946

https://doi.org/10.15388/infedu.2016.13

Ogena, E.B., Lana, R.D., \& Sasota, R.S. (2010). Performance of Philippine High Schools with special curriculum in the 2008 trends in International Mathematics and Sciences study (TIMSS-Advanced). Research Presented during the $11^{\text {th }}$ National Convention on Statistics. October 4-5. Available at: goo.gl/TXci8V

Oktaviyanthi, R., \& Supriani, Y. (2014). Educational Technology: Applying Microsoft Mathematics to enrich students' mathematics learning and increase motivation. International Journal of Education and Research, 2(7), 317-328. Available at: goo.gl/tdyiTE

Özgün-Koca, S.A. (2010). Prospective teachers' views on the use of calculators with computer algebra system in algebra instruction. Journal of Mathematics Teacher Education, 13(1), 49-71.

https://doi.org/10.1007/s10857-009-9126-z

Pierce, R., Stacey, K., \& Barkatsas, A. (2007). A scale for monitoring students' attitudes to learning mathematics with technology. Computers \& Education, 48(2), 285-300.

https://doi.org/10.1016/j.compedu.2005.01.006

Prasek, M, Schwartz, A., \& Vorst, K.V. (2012). Technology integration: Effects on motivation, engagement, \& interests. Lithuania.

Purwanti, D.E., \& Pustari, M. (2013). The comparison of using Microsoft Mathematics and traditional teaching on students' achievement-teaching mathematics in senior high school. Proceedings of the Global Summit of Education, Malaysia. Available at: https://worldconferences.net/proceedings/gse2013/papers gse2013/255\%20Dian\%20Eki\%20Purwanti.pdf

Richland, L.E., Stigler, J.W., \& Holyoak, K.J. (2012). Teaching the conceptual structure of mathematics. Educational Psychologist, 47(3), 189-203. https://doi.org/10.1080/00461520.2012.667065

Rittle-Johnson, B., \& Schneider, M. (2014). Developing conceptual and procedural knowledge of mathematics. Oxford handbook of numerical cognition, 1102-1118. Available at: goo.gl/nNKSdD

Robutti, O. (2010). Graphic calculators and connectivity software to be a community of mathematics practitioners. ZDM, 42(1), 77-89. https://doi.org/10.1007/s11858-009-0222-4

Saavedra, A.R., \& Opfer, V.D. (2012). Learning $21^{\text {st }}$ century skills requires $21^{\text {st }}$ century teaching. Phi Delta Kappan, 94(2), 8-13. https://doi.org/10.1177/003172171209400203

Safdar, A., Yousuf, M.I., Parveen, Q., \& Behlol, M.G. (2011). Effectiveness of information and communication technology (ICT) in teaching mathematics at secondary level. International Journal of Academic Research, 3(5). Available at: goo.gl/h3Nf8b

Sahin, A., Cavlazoglu, B., \& Zeytuncu, Y.E. (2015). Flipping a college calculus course: A Case study. Journal of Educational Technology \& Society, 18(3), 142. Available at: http://www.jstor.org/stable/jeductechsoci.18.3.142

Salazar, D.A. (2016). Methods of grouping in a flipped classroom model: Effects on students' achievement in differentral calculus. Methods, 1(5). Available at: goo.gl/b8gV7i 
Salleh, S.T., \& Zakaria, E. (2011). Integrating computer algebra system (CAS) into integral calculus teaching and learning at the university. International Journal of Academic Research, 3(3), 397-401. Available at: http://www.academia.edu/1330128/INTEGRATING COMPUTER ALGEBRA SYSTEMS CAS INTO INT EGRAL CALCULUS TEACHING AND LEARNING AT THE UNIVERSITY

Salleh, T.S.A., \& Zakaria, E. (2013). Fostering students' understanding in integral calculus through maple activities. Energy Education Science and Technology Part B: Social and Educational Studies, 5(2), 303-310. Available at: goo.gl/JPGcLh

Sang, G., Valcke, M., Van Braak, J., \& Tondeur, J. (2010). Student teachers' thinking processes and ICT integration: Predictors of prospective teaching behaviors with educational technology. Computers \& Education, 54(1), 103-112. https://doi.org/10.1016/j.compedu.2009.07.010

Schumacher, P., \& Kennedy, K.T. (2008). Lessons learned concerning a student-centered teaching style by university mathematics professors from secondary school educators. Education, 129(1), 102-110. Available at: goo.gl/8ThiA1

Šumonja, S., Veličković, V., \& Šubarević, T. (2015). Applying ICT in the teaching of mathematics in high school. IMVI Open Mathematical Education Notes, 5(1), 31-46. Available at: http://oaji.net/articles/2015/484-1423741289.pdf

Tall, D. (2008). The transition to formal thinking in mathematics. Mathematics Education Research Journal, 20(2), 5-24. https://doi.org/10.1007/BF03217474

Tay, L.Y., Lim, S.K., Lim, C.P., \& Koh, J.H.L. (2012). Pedagogical approaches for ICT integration into primary school English and mathematics: A Singapore case study. Australasian journal of educational technology, 28(4). https://doi.org/10.14742/ajet.838

Tindowen, D.J.C., Bassig, J.M., \& Cagurangan, J.A. (2017). Twenty-First-Century Skills of Alternative Learning System Learners. SAGE Open, 7(3). https://doi.org/2158244017726116

Tiwari, T.K. (2007) Computer graphics as an instructional aid in an introductory differential calculus course. International Electronic Journal of Mathematics Education 2(1), 32-48. Available at: http://www.ieime.com/012007/d3.pdf

Yuan, Y., \& Chun-Yi, L.E.E. (2012). Elementary school teachers' perceptions toward ICT: The case of using magic board for teaching mathematics. TOJET: The Turkish Online Journal of Educational Technology, 11(4). Available at: goo.gl/EtxVLX

Zakaria, E., \& Salleh, T. S. (2015). Using technology in learning integral calculus. Mediterranean Journal of Social Sciences, 6(5), 144. https://doi.org/10.5901/mjss.2015.v6n5s1p144

Published by OmniaScience (www.omniascience.com)

Journal of Technology and Science Education, 2018 (www.jotse.org)

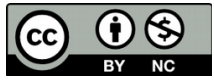

Article's contents are provided on an Attribution-Non Commercial 4.0 Creative commons International License.

Readers are allowed to copy, distribute and communicate article's contents, provided the author's and JOTSE journal's names are included. It must not be used for commercial purposes. To see the complete licence contents, please visit https://creativecommons.org/licenses/by-nc/4.0/. 